Original Article

\title{
OPTIMIZED AND VALIDATED SPECTROPHOTOMETRIC METHOD FOR THE DETERMINATION OF AMPICILLIN IN PHARMACEUTICAL FORMULATIONS
}

\author{
SK MANIRUL HAQUE \\ Department of Chemical and Process Engineering Technology, Jubail Industrial College, P. 0. Box 10099, Jubail Industrial City 31961, \\ Saudi Arabia \\ Email: Haque_m@jic.edu.sa \\ Received: 17 Oct 2020, Revised and Accepted: 18 Dec 2020
}

\section{ABSTRACT}

Objective: A simple, precise, and accurate spectrophotometric method has been developed to determine Ampicillin in pharmaceutical formulations.

Methods: The proposed method, based on the carboxylic acid group reaction, present in Ampicillin with a mixture of $\mathrm{KIO}_{3}$ and $\mathrm{KI}$, form a yellowcolored product in an aqueous medium. The response was allowed to proceed at $25 \pm 1^{\circ} \mathrm{C}$, and absorbance measured after 5 min against a reagent blank prepared simultaneously using a UV-Vis spectrophotometer. The parameters verified were specificity, linearity, linearity range, accuracy, precision, detection limit, quantitation limit, robustness, and ruggedness.

Results: The yellow-colored product was measured at $352 \mathrm{~nm}$ against the reagent blank using UV-Vis spectrophotometer. The linear dynamic range of concentration was $0.25-2.5 \mu \mathrm{g} / \mathrm{ml}$ with a correlation coefficient of 0.9999 . The LOD, LOQ values to be $0.086 \mathrm{and} 0.261 \mu \mathrm{g} / \mathrm{ml}$, respectively, for the proposed method. The percentage of recoveries was $98.27-100.89 \%$ with an acceptable relative standard deviation $( \pm 2 \%)$. The robustness and ruggedness values were excellent.

Conclusion: The ICH guidelines for pharmaceuticals and human use were followed and applied to validate the proposed method. The method was compared with available literature and found similar results that confirmed the reliability and effective way for Ampicillin's determination.

Keywords: Ampicillin, Potassium iodate, Potassium iodide, Spectrophotometer, Method development, Validation, Tablets

(C) 2021 The Authors. Published by Innovare Academic Sciences Pvt Ltd. This is an open access article under the CC BY license (https://creativecommons.org/licenses/by/4.0/) DOI: https://dx.doi.org/10.22159/ijpps.2021v13i2.40025. Journal homepage: https://innovareacademics.in/journals/index.php/ijpps.

\section{INTRODUCTION}

Ampicillin is semi-synthetic antibiotics with broad antimicrobial properties., chemically known as $(2 \mathrm{~S}, 5 \mathrm{R}, 6 \mathrm{R})-6-([(2 \mathrm{R})-2$-amino-2phenylacetyl]amino)3,3-dimethyl-7-oxo-4-thia-1-azabicyclo[3.2.0] heptane-2-carboxylic acid (fig. 1). It is an amphoteric compound and acts as an aliphatic amino acid. It has been a therapeutic drug against many gram-positive microorganisms. It is still more active with gram-negative microorganisms due to its enhanced ability to penetrate the bacteria through the outer membrane.

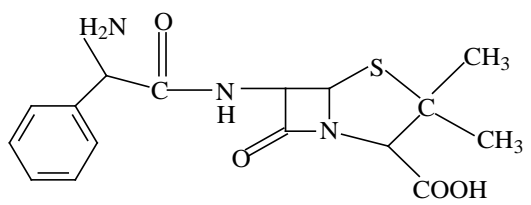

Fig. 1: Structure of penicillin-type antibiotic drug, Ampicillin

Ampicillin is available in tablets, capsules, powder for oral suspension and injection as commercial usage since 1961 [1]. The extensive literature survey revealed that several analytical techniques, likely as high-performance liquid chromatography (HPLC) [2, 3], capillary electrophoresis (CE) [4, 5], Fouriertransform infrared spectroscopy (FTIR) [6] were available for the determination in bulk and pharmaceutical formulations. It can be quantified with liquid chromatography-mass spectrophotometry (LCMS) [7] and ultra-performance liquid chromatography-mass spectrophotometry (UPLC-MS) [8] in biological fluids. Most of the techniques are involved with the complicated procedure, extraction with toxic solvents, and expensive instrumentation and pretreatment of the sample before analysis. However, UltravioletVisible (UV-Vis) spectrophotometer is a convenient technique for the study of pharmaceuticals. Generally, the quantification without any pretreatment procedure before analysis [9-13]. Ampicillin as well can be quantified in bulk and drugs [14, 15]. The presented paper describes a fast, sensitive, and economical method for determining Ampicillin in pharmaceutical formulations. The procedure was based on the reaction of a carboxylic acid group of Ampicillin with a mixture of potassium iodate $\left(\mathrm{KIO}_{3}\right)$ and potassium iodide (KI) to form a yellow-colored product in an aqueous medium at room temperature $\left(25^{\circ} \mathrm{C}\right)$, followed spectrophotometrically by measuring the absorbance at $352 \mathrm{~nm}$.

\section{MATERIALS AND METHODS}

Apparatus

The spectrophotometer, Cecil (CE 7400, UK), with a $1 \mathrm{~cm}$ glass cell was applied to carry out all the spectral runs.

\section{Materials and reagents}

The pharmaceutical formulation products of Ampicillin such as Ampicyn 500 (Cipla Limited, India), Campicillin 250 (Cadila Pharmaceuticals, India), and Ampiclox 500 (GlaxoSmithKline, UK) were brought from the local pharmacy. Potassium iodate and potassium iodide purchased from Sigma Aldrich, USA, and prepared solutions in distilled water with $2.5 \times 10^{-3}$ and $2.5 \times 10^{-2} \mathrm{M}$, respectively.

\section{Extraction of ampicillin from the dosage form}

Ampicillin (500 mg/capsule) powder materials were transferred into a $250 \mathrm{ml}$ volumetric flask and dissolved with distilled water The separation was continued with column chromatography using silica gel as a stationary phase and water: methanol: glacial acetic acid (1.2: 8.5: $0.3 \mathrm{v} / \mathrm{v} / \mathrm{v}$ ) as mobile phase. The target compound was separated and dried as solid Ampicillin.

\section{Standard Ampicillin solutions}

The standard Ampicillin solution $(50 \mu \mathrm{g} / \mathrm{ml})$ was prepared in distilled water and diluted as per the requirement. 


\section{Optimization of variables}

The parameters were thoroughly studied related to the color development of the product. Therefore, several conditions were optimized during quantification and maintained their optimum value throughout the determination process.

\section{Potassium iodate $\left(\mathrm{KIO}_{3}\right)$ concentration}

The effect of volume of potassium iodate $\left(2.5 \times 10^{-3} \mathrm{M}\right)$ was investigated in the range of $0.1-1.5 \mathrm{ml}$, keeping ampicillin $(2.5$ $\mu \mathrm{g} / \mathrm{ml})$ and $\mathrm{KI}\left(1.25 \times 10^{-3} \mathrm{M}\right)$ as constant. The absorbance was increased with the increasing volume of $\mathrm{KIO}_{3}$ and became steady at $1.1 \mathrm{ml}$. Further addition of work does not have any impact on the color development of the product. Therefore, $1.3 \mathrm{ml}$ used as an optimum volume throughout the experiment for $\mathrm{KIO}_{3}$.

\section{Potassium iodide (KI) concentration}

The effect of volume of potassium iodide $\left(2.5 \times 10^{-2} \mathrm{M}\right)$ was investigated for product's color development in the range of $0.2-2.2$ $\mathrm{ml}$, keeping ampicillin $(2.5 \mu \mathrm{g} / \mathrm{ml})$ and $\mathrm{KIO}_{3}\left(7.5 \times 10^{-5} \mathrm{M}\right)$ as constant. The maximum intensity of the colored product gave rise to $1.8 \mathrm{ml}$ of KI, and a further increase in the volume did not affect the absorbance. Thus, the proposed procedure used $2 \mathrm{ml}$ as constant throughout the experiment for KI.

\section{The proposed procedure for the determination of Ampicillin}

Into a series of $50 \mathrm{ml}$ volumetric flasks, different volumes of Ampicillin $(50 \mu \mathrm{g} / \mathrm{ml})$ corresponds to $0.25-2.50 \mu \mathrm{g} / \mathrm{ml}$ added with 2 $\mathrm{ml}$ of $\mathrm{KI}\left(2.5 \times 10^{-2} \mathrm{M}\right)$ and $1.3 \mathrm{ml}$ of $\mathrm{KIO}_{3}\left(2.5 \times 10^{-3} \mathrm{M}\right)$. The final volume was made up of distilled water and shook the mixture well enough to mix them properly. The reaction's equilibrium achieves after $5 \mathrm{~min}$; therefore, $5 \mathrm{~min}$ is used as the equilibrium time for its determination. Absorbance was recorded for all standard samples at $352 \mathrm{~nm}$ and applied to construct a regression equation against
Ampicillin's initial concentrations [16]. The intraday and interday precision of the proposed methods were established by measuring Ampicillin's content at three different concentration levels (low, medium, and high) at 0.5 .1 .25 and $2 \mu \mathrm{g} / \mathrm{ml}$ within one day and five consecutive days, respectively. Ampicillin, with a known amount $(0.5 \mu \mathrm{g} / \mathrm{ml})$ in dosage form, was spiked with $100 \%, 200 \%$, and $300 \%$ of additional Ampicillin pure drug, respectively, and determine the accuracy, precision of the proposed method following the recommended procedure as ICH guidelines [17-19].

\section{Analysis of pharmaceutical formulations}

Two ampicillin (label claim: $250 \mathrm{mg}$ ) capsules were mixed with 250 $\mathrm{ml}$ distilled water and kept for $30 \mathrm{~min}$ after stirred. After filtration to recover the drugs completely, repeated the washing steps several times. This solution was used for further process and applied the above procedure to determine the Ampicillin in pharmaceutical formulations

\section{RESULTS AND DISCUSSION}

\section{Reaction with a mixture of iodide and iodate}

The literature reported [20] iodine formed by the interaction between potassium iodate and potassium iodide due to organic and inorganic acid reaction by the below equation.

$$
5 \mathrm{I}^{-}+\mathrm{IO}_{3}{ }^{-}+6 \mathrm{H}^{+} \rightarrow 3 \mathrm{H}_{2} \mathrm{O}+3 \mathrm{I}_{2}
$$

The liberated iodine reacted with excess iodide ions to yield a triiodide ion $\left(\mathrm{I}_{2}+\mathrm{I}^{-} \rightarrow \mathrm{I}_{3}{ }^{-}\right)$, which absorbs maximally at $352 \mathrm{~nm}$. It was the fundamental mechanism to develop a spectrophotometric method for Ampicillin as it contains- $\mathrm{COOH}$ group in its moiety. The reaction mechanism suggested in Scheme 1 as per the above reaction. The communicated process corresponds to Ampicillin $(0.25-2.50 \mu \mathrm{g} / \mathrm{ml})$ was reacted with $1.3 \mathrm{ml} \mathrm{KIO}_{3}$ (fig.2) and $2 \mathrm{ml}$ $\mathrm{KIO}_{3}$ (fig. 3) mixture and formed yellow-colored triiodide ions.

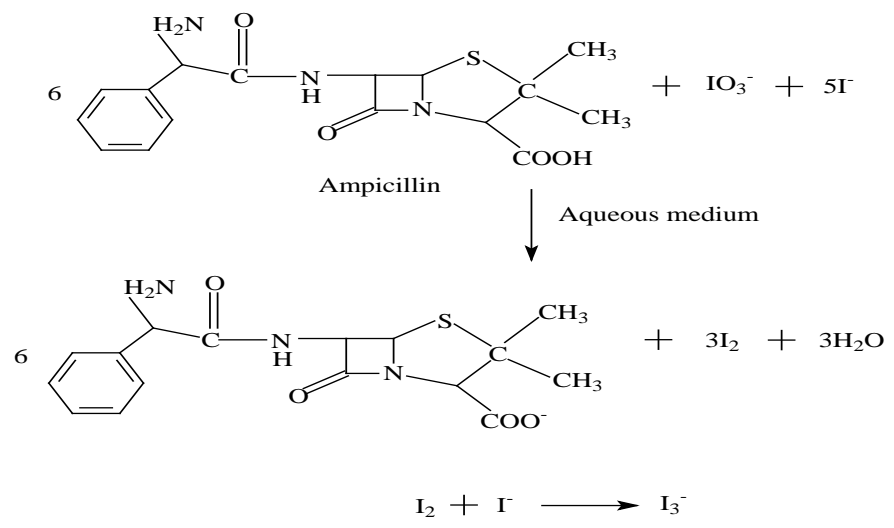

Scheme 1: Formation of triiodide ion that measures spectrophotometrically at $352 \mathrm{~nm}$

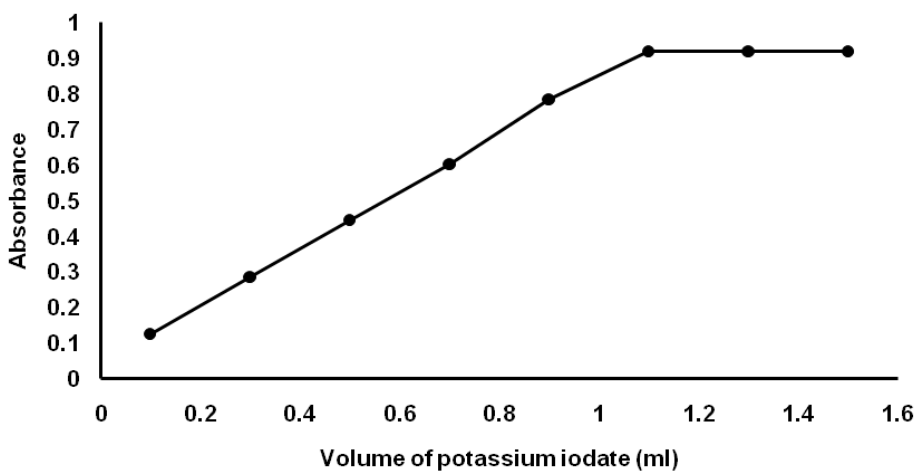

Fig. 2: Effect of the volume of potassium iodate $\left(2.5 \times 10^{-3} \mathrm{M}\right)$ on the absorbance of the product, Ampicillin $(2.5 \mu \mathrm{g} / \mathrm{ml})$, and $\mathrm{KI}\left(1.25 \times 10^{-3} \mathrm{M}\right)$ 


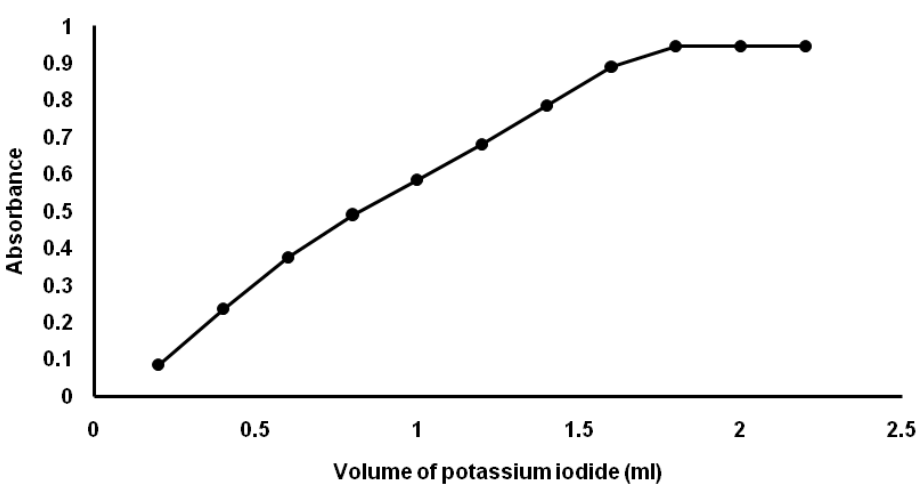

Fig. 3: Effect of the volume of potassium iodide $\left(2.5 \times 10^{-2} \mathrm{M}\right)$ on the absorbance of the product, Ampicillin $(2.5 \mu \mathrm{g} / \mathrm{ml})$, and $\mathrm{KIO}_{3}\left(7.5 \times 10^{-5} \mathrm{M}\right)$

\section{Validation of proposed methods}

\section{Specificity}

The proposed method's specificity was evaluated by preparing a synthetic mixture of bulk drugs with common excipients used in the tablet formulations. It observed that no interference of excipients during the quantification drug.

\section{Linearity and linear range}

Under the optimized experimental conditions, the absorbance and concentration were linear within the range of $0.25-2.5 \mu \mathrm{g} / \mathrm{ml}$ (fig. 4). The statistical treatment of the data yielded the linear regression equation $\mathrm{A}=0.0035+0.4227 \mathrm{C}$. The statistical regression data provided the slope, intercept, detection limits, quantitation, and results summarized in table 1 . All the parameters were important as per the guidelines and considered during the validation of the developed method.

\section{Accuracy and precision}

The intraday and interday precision have resulted in an Ampicillin concentration of $0.5,1.25$, and $2 \mu \mathrm{g} / \mathrm{ml}$ (table 2). The \% RSD was in the range of $0.24-1.81 \%$ within $\pm 2 \%$. The recovery studies of each concentration level established the accuracy of the method. The procedure's \% recovery was in the range of $99.32-100.65 \%$ (table 3) within the acceptable limit of $98-102 \%$, as per ICH guidelines [17-19].

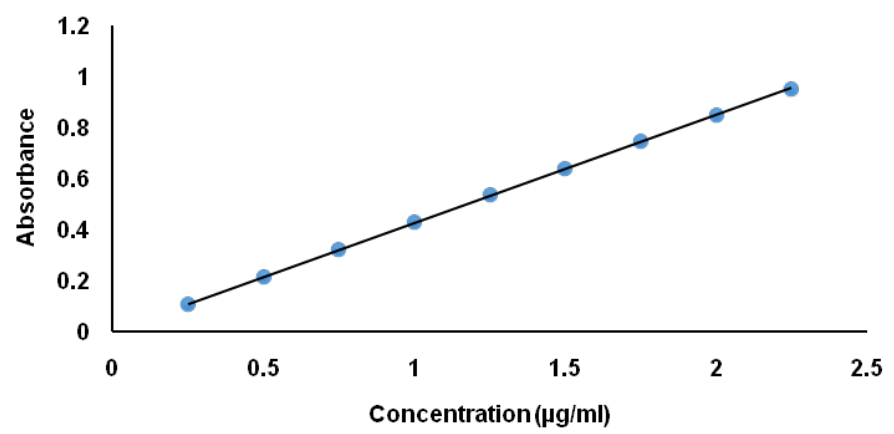

Fig. 4: Linearity of the proposed method

Table 1: Optical and regression characteristics of the proposed method

\begin{tabular}{ll}
\hline Parameters & Values \\
\hline$\lambda_{\max }$ & $352 \mathrm{~nm}$ \\
Calibration equation & $\mathrm{A}=0.0035+0.4227 \mathrm{C}$ \\
Linear dynamic range $(\mu \mathrm{g} / \mathrm{ml})$ & $0.25-2.5$ \\
Standard Deviation $\left(\mathrm{S}_{0}\right)$ & $1.1 \times 10^{-2}$ \\
Slope $(\mathrm{m})$ & $4.22 \times 10^{-1}$ \\
Correlation coefficient $\left(\mathrm{r}^{2}\right)$ & 0.9999 \\
Detection limit $(\mu \mathrm{g} / \mathrm{ml})$ & 0.086 \\
Quantitation limit $(\mu \mathrm{g} / \mathrm{ml})$ & 0.261 \\
\hline
\end{tabular}

Table 2: Summary of accuracy and precision results of the proposed method

\begin{tabular}{|c|c|c|c|c|}
\hline \multirow[t]{2}{*}{ Proposed method } & \multicolumn{2}{|c|}{ Amount $(\mu \mathrm{g} / \mathrm{ml})$} & \multirow[t]{2}{*}{ \% Recovery } & \multirow[t]{2}{*}{ \% RSD } \\
\hline & Taken & Found $\pm S D^{a}$ & & \\
\hline \multirow[t]{3}{*}{ Intraday } & 0.75 & $0.756 \pm 0.014$ & 100.89 & 1.81 \\
\hline & 1.50 & $1.497 \pm 0.004$ & 99.81 & 0.24 \\
\hline & 2.25 & $2.234 \pm 0.006$ & 99.27 & 0.27 \\
\hline \multirow[t]{3}{*}{ Interday } & 0.75 & $0.741 \pm 0.014$ & 98.78 & 1.84 \\
\hline & 1.50 & $1.502 \pm 0.005$ & 100.12 & 0.328 \\
\hline & 2.25 & $2.231 \pm 0.01$ & 99.17 & 0.441 \\
\hline
\end{tabular}

aMean for five independent analyses, SD, standard deviation, RSD, relative standard deviation 
Table 3: Summary of accuracy and precision results of the proposed method for ampicillin pharmaceutical formulations

\begin{tabular}{|c|c|c|c|c|}
\hline \multirow[t]{2}{*}{ Proposed method } & \multicolumn{2}{|c|}{ Amount $(\mu \mathrm{g} / \mathrm{ml})$} & \multirow[t]{2}{*}{ \% RSD } & \multirow[t]{2}{*}{ \% Recovery } \\
\hline & Taken & Found $\pm S D^{a}$ & & \\
\hline Ampicyn-500 & 1.0 & $0.993 \pm 0.014$ & 1.375 & 99.32 \\
\hline Ampicyn-500 & 1.5 & $1.508 \pm 0.004$ & 0.239 & 100.65 \\
\hline Ampicyn-500 & 2.0 & $2.000 \pm 0.002$ & 0.118 & 100.01 \\
\hline Campicilin-250 & 1.0 & $0.993 \pm 0.014$ & 1.375 & 99.32 \\
\hline Campicilin-250 & 1.5 & $1.508 \pm 0.007$ & 0.471 & 100.54 \\
\hline Campicilin-250 & 2.0 & $2.001 \pm 0.001$ & 0.068 & 100.05 \\
\hline Ampiclox-500 & 1.0 & $0.993 \pm 0.014$ & 1.375 & 99.32 \\
\hline Ampiclox-500 & 1.5 & $1.508 \pm 0.004$ & 0.239 & 100.65 \\
\hline Ampiclox-500 & 2.0 & $2.000 \pm 0.002$ & 0.118 & 100.01 \\
\hline
\end{tabular}

aMean for five independent analyses, SD, standard deviation, RSD, relative standard deviation, bSAE, standard analytical error, ${ }^{\mathrm{c}} \mathrm{C}$. L., confidence limit at $95 \%$ confidence level and 4 degrees of freedom $(t=2.776)$

\section{Robustness}

The robustness study was performed at different laboratories. The due reason recorded the absorbance after $4.5 \mathrm{~min}$ and well continued for $5.5 \mathrm{~min}$ of reaction. The investigation resulted at 351 $\mathrm{nm}$ and $353 \mathrm{~nm}$ to check the method's robustness. The procedure's $\%$ recovery was in the range of 98.32-99.97\% and \% RSD between 0.352-0.755\%, respectively, within the acceptable limit.

\section{Ruggedness}

The ruggedness test was conducted at three different concentration levels within the linearity range. The test was expressed in terms of \%RSD, applied the same procedure using another UV-Vis spectrophotometer. The procedure's \% recovery was within 98.55-
$99.72 \%$ and \% RSD between $0.023-0.325 \%$ within the acceptable limit of $\pm 2 \%$.

\section{Application of the proposed method}

The proposed method was successfully developed and validated for the determination of Ampicillin in pharmaceutical formulations. The proposed method was compared with the reference method [3] using point and interval hypothesis tests. The calculated t-(paired) and F-values at 95\% confidence level do not exceed the theoretical ones indicating any significant differences between the developed method's performances with the reference method (table 4). Table 4 showed that all samples of the drug's actual bias were smaller than $\pm 2 \%$ and thus confirming that the proposed method was reliable with acceptable recovery.

Table 4: Point and interval hypothesis tests: comparing the proposed methods with the reference method at $95 \%$ confidence level

\begin{tabular}{|c|c|c|c|c|c|c|}
\hline \multirow[t]{2}{*}{ Formulations } & \multicolumn{3}{|c|}{ Proposed method } & \multicolumn{3}{|c|}{ Reference method } \\
\hline & \% Recovery & \% RSD & $t$-and $F$ b & $\theta_{\mathrm{L} \text { and }} \theta_{\mathrm{U}} \mathrm{c}$ & \% Recovery & \% RSD \\
\hline Ampicyn-500 & 99.91 & 0.25 & $\begin{array}{l}\mathrm{t}=0.016 \\
\mathrm{~F}=1.022\end{array}$ & $\begin{array}{l}\theta_{L}=0.989 \\
\theta_{U}=1.004\end{array}$ & 99.94 & 0.35 \\
\hline Campicilin-250 & 99.93 & 0.16 & $\begin{array}{l}\mathrm{t}=0.121 \\
\mathrm{~F}=1.83\end{array}$ & $\begin{array}{l}\theta_{L}=0.984 \\
\theta_{U}=1.015\end{array}$ & 99.92 & 0.31 \\
\hline Ampiclox -500 & 99.91 & 0.22 & $\begin{array}{l}\mathrm{t}=0.461 \\
\mathrm{~F}=1.48\end{array}$ & $\begin{array}{l}\theta_{\mathrm{L}}=0.992 \\
\theta_{\mathrm{U}}=1.003\end{array}$ & 99.81 & 0.55 \\
\hline
\end{tabular}

Theoretical $\mathrm{t}-(v=8)$ and F-values $(v=4,4)$ at $95 \%$ confidence level are 2.306 and 6.39 , respectively. $\theta_{\mathrm{L}}$ and $\theta_{\mathrm{u}}$ are within the acceptable limits of $\pm 2 \%$.

\section{CONCLUSION}

The proposed UV-Vis technique is a simple, low-cost method and can easily be applied to Ampicillin's routine quality control sample analysis in bulk and pharmaceutical formulations. It has a more comprehensive dynamic range for the study with excellent accuracy and precision value. The proposed method does not require any laborious cleanup procedure before analysis and simple methodology for its determination. Therefore, it can easily accommodate in the laboratories of research, hospitals, and pharmaceutical industries for the quantification of Ampicillin in pure and pharmaceutical dosage forms.

\section{FUNDING}

Nil

\section{AUTHORS CONTRIBUTIONS}

Single author and contributed all.

\section{CONFLICT OF INTERESTS}

The author report no conflicts of interest.

\section{REFERENCES}

1. Tadesse DA, Zhao S, Tong E, Ayers S, Singh A, Bartholomew MJ, et al. Antimicrobial drug resistance in escherichia coli $\mathrm{f}+$ rom humans and food animals, United States, 1950-2002. Emerg Infect Dis 2012;18:741-9.

2. Ahmed MS, Mohammed RH, Fadhil MA. RP-HPLC method validation for the determination of Ampicillin in Iraqi healthy volunteers serum. Int J Res Pharm Chem 2017;7:360-6.

3. Barot TG, Patidar K, Kshartri N, Vyas N. Development and validation of LC method for the determination of Ampicillin and dicloxacillin in pharmaceutical formulation using an experimental design. E J Chem 2009;6:955-64.

4. Simon B, Hancu G, Gyeresi A. Application of capillary electrophoresis to the simultaneous determination and stability study of four extensively used penicillin derivatives. Brazilian J Pharma Sci 2014;50:521-7.

5. Long C, Deng B, Sun S, Meng S. Simultaneous determination of chlortetracycline, Ampicillin and sarafloxacin in milk using capillary electrophoresis with electrochemiluminescence detection. Food Additives Contaminants Part A Chem Anal Control Exp Risk Assess 2017;34:24-31.

6. Totoli EG, Salgado HRN. Development and validation of the quantitative analysis of ampicillin sodium in powder for injection by fourier-transform infrared spectroscopy (FT-IR). Phys Chem 2012;2:103-8.

7. Chen L, Wang B, Diao Z, Zhao M, Xie K, Zhang P, Wang X, Zhang T, Wang J. Development and validation of an HPLC-ESI/MS/MS method for the determination of amoxicillin, its major 
metabolites, and ampicillin residues in chicken tissues. Molecules 2019;24:2652.

8. Parker SL, Adnan S, Meija JLO, Paterson DL, Lipman J, Roberts $\mathrm{JA}$, et al. A UHPLC-MS/MS method for the simultaneous determination of Ampicillin and sulbactam in human plasma and urine. Bioanal 2015;7:2311-9.

9. Pallavi K, Babu PS, Babu GK. Development and validation of UV spectrophotometric method and RP-HPLC method for estimation of capecitabine in bulk and tablet dosage forms. Int Appl Pharm 2016;8:24-9.

10. Madur S, Matole V, Kalshetti M. UV visible spectrophotometric method development and validation of dasatinib in bulk and solid dosage form. Int J Curr Pharm Res 2020;12:90-3.

11. Rai G, Kumar A. Screening and analysis of FTO gene polymorphism in north UP (India). J Critical Rev 2020;7:2274-80.

12. Supriya P, Madhavi LN, Rohith KBV, Ramana GV, Harini U, Pawar AKM. Development and validation of UV spectrophotometric and reversed-phase high-performance liquid chromatography-PDA methods for the estimation of alogliptin benzoate. Asian J Pharm Clin Res 2016;9:282-7.

13. Khanchandani SS, Galgatte UC, Chaudhari PD. Development and validation of UV-visible spectroscopic method for estimation of rizatriptan benzoate in bulk and tablet dosage form. Asian J Pharm Clin Res 2013;6:113-6.
14. Ezeanokete CC, Ngwoke KG, Okoye FBC, Osadebe PO. Spectrophotometric determination of Ampicillin and cloxacillin in pure and fixed dosage forms through charge transfer complexation. Eur Chem Bull 2013;2:1009-12.

15. Misic IR, Miletic G, Mitic S, Mitic M, Marinkovic EP. A simple method for the ampicillin determination in pharmaceuticals and human urine. Chem Pharma Bull 2013;61:913-9.

16. Ahmed AJ, Abdulla S, Yunusa U, Omar A, Haque SM. Development, computational studies and validation of spectrophotometric method of metformin hydrochloride in pharmaceutical formulations. J Chilean Chem Soc 2020;65:4895-9.

17. United States Food and Drug Administration. Guideline for industry: text on validation of analytical procedures: ICH Q2A 1995.

18. United States Food and Drug Administration. Guidance for industry: Validation of analytical procedures: methodology, Q2B; 1996.

19. International conference on the harmonization of the technical requirements for registration of pharmaceuticals for human use, ICH harmonized tripartite guideline, validation of analytical procedures: text and methodology, Q2 (R1); 1996.

20. Feigl F. Spot tests in the organic analysis. Chapter 3: Preliminary (Exploratory tests). $6^{\text {th }}$ edition. Elsevier publishing company, Amsterdam; 1960. p. 117-8. 